\title{
IDEOLOGICAL SKIRMISHES BETWEEN NATIONALIST AND COMMUNIST YOUTH AT THE FACULTY OF ORTHODOX THEOLOGY IN BELGRADE (1936-1941)
}

\section{Aleksandar RAKOVIĆ*}

\begin{abstract}
According to the archival documentation of the Faculty of Orthodox Theology of the University of Belgrade, students' press and literature, the paper shows ideological skirmishes between nationalist and communist youth at the Faculty of Orthodox Theology in Belgrade between 1936 and 1941 and analyses the way the communists acted towards divided students' organizations and groups.
\end{abstract}

Keywords. Faculty of Orthodox Theology, University of Belgrade, Kingdom of Yugoslavia, skirmish, ideologies.

In the second half of the 1930s, students' newspaper Studentske novine was quite involved with communist propaganda at the University of Belgrade. In the middle of the 1930s, the communists already established control over the majority of specialized student organizations, and by the end of a decade their impact grew even stronger ${ }^{1}$. Although, at the end of 1937, Studentske novine claimed that the students of the Faculty of Orthodox Theology were "compact", this faculty did not lack communist propaganda ${ }^{3}$. The promoters just acted more properly.

From 1934 to 1941, the Communist Party of Yugoslavia also acted

* Senior Research Fellow, Institute for Recent History of Serbia, Belgrade.

${ }^{1}$ Dragomir Bondžıć, Beogradski univerzitet 1944-1952, Belgrade, Institut za savremenu istoriju, 2004, p. 45-48.

$2 * * *$ "Before the Assembly of the Association and Choir of Theology Students", in Studentske novine, $10^{\text {th }}$ of November 1937.

${ }^{3}$ Đoko SLIJEPČEVIĆ, Istorija srpske pravoslavne crkve, III, Belgrade, BIGZ, 1991, p. 1621. 
through the Action Committee of Specialized Student Associations (Akcioni odbor stručnih studentskih udruženja - AOSSU) at the University of Belgrade. The work of this body was inseparable from the work of the League of Communist Youth of Yugoslavia (Savez komunističke omladine Jugoslavije - SKOJ). At the Faculty of Orthodox Theology, starting from 1936, a unit of the Action Committee of Specialized Student Associations acted within the framework of the Association of Students of the Faculty of Orthodox Theology 4 .

Đoko Slijepčević and Dragoljub Vurdelja, two ideologically opposed anti-communists, clarified the way the communists entered the Faculty of Orthodox Theology. Slijepčević explained that many leftists who studied at the Faculty of Orthodox Theology were prone to communist propaganda as well as that the communists at the Faculty of Orthodox Theology were few, but that their activity was "devastating". Some of them were "intentionally" sent to study theology for the purpose of ideological indoctrination ${ }^{5}$. Vurdelja observed that there were some theologians and priests who were "filo-communists and communists after conviction": "Until 1941, theological education and priesthood served them as a perfect cover. The Communist Party of Yugoslavia had relevant records about all of them and only those uninformed were surprised by a number of priests who became partisans overnight"6.

Regarding the Association of Students of the Faculty of Orthodox Theology, it should be pointed out that Živojin Munjić came to the head of this Association in 1936. At the end of 1937, the old leadership of the Association of Students of the Faculty of Orthodox Theology, which again was led by Živojin Munjić, was re-elected ${ }^{7}$. In 1964, Vurdelja marked Munjić as one of those who "ideologically belonged to communism" even before the Second World War, but formally joined the Communist Party of Yugoslavia after the war ${ }^{8}$. In already confronting Association of Students of the Faculty of Orthodox Theology, Munjić's re-election opened a new crisis that was

\footnotetext{
${ }^{4}$ Milica DamuAnOvić, Napredni pokret studenata Beogradskog univerziteta, II, Belgrade,

Nolit, 1974, p. 324-326. In the same book, see footnote 656 on page 326.

5 Đoko SLIJEPČEVIĆ, op. cit., p. 16-21.

${ }^{6}$ Dragoljub G. Vurdelua, Obezglavljena Srpska crkva, I, Trieste, 1964, p. 62.

7 *** "Beleške", in Svetosavlje, December, 1937, Beograd, p. 156.

${ }^{8}$ Dragoljub G. VurdeluA, op. cit., p. 63.
} 
also observed in the student's press.

At the end of 1937, Studentske novine wrote that among the students of the Faculty of Orthodox Theology "there was a gap that would not be easily overcome". The responsibility for the conflicts among students was assigned to the leadership of the Association of Students of the Faculty of Orthodox Theology, which made "a series of tactical mistakes, often unconsciously, and perhaps in good faith, which led to very unfavourable consequences". In conclusion, the newspapers wrote: "It is necessary to calm down the passions, settle down the skirmishes and start a new year with enthusiasm which has always been typical of the Faculty of Orthodox Theology. Hopefully, reason will win and theologians will be able to face the challenges that may be waiting for them this year",

Studentske novine were somewhat inconsistent when writing about: 1) "a gap that would not be easily overcome", and 2) "little skirmishes". It was rather the first one. The reason for the "gap" was seen in personal conflicts and poor performance. It was truth, no doubt, but the possible ideological motive was completely neglected. It was intentionally concealed or overlooked. The leadership of the Association of Students of the Faculty of Orthodox Theology kept its intentions secret until the very end ${ }^{10}$.

In the late 1938, the Association of Students of the Faculty of Orthodox Theology was faced with reorganization. The leadership decided to take responsibility for mistakes that occurred because of the "distance" from the members. The Association called upon a professional discussion and convened a "social meeting" in November 1938: "At the meeting, the management proposed drafting a list which would include all the people who were most convenient candidates for the leadership, for whom no serious objections could be made and who would not be leaders of the opposed groups of students. Theoretically, everybody was for drafting such a list, but many doubted the possibility of its drafting.

9 *** "Assembly of the Association and Choir of Theology Students", in Studentske novine, $10^{\text {th }}$ of November 1937.

${ }^{10}$ Archives of the Faculty of Orthodox Theology (Arhiva pravoslavnog bogoslovskog fakulteta - hereinafter: APBF), Minutes from the meeting of the Council of the Faculty of Orthodox Theology, 30 June 1939. 
The chairperson ended a meeting with a promise that the management would try to draw up such a list, invite all those who wanted such a list to be drafted and convince others that it was all possible and done in good faith" "11. This article shows that the relations among the students of the Faculty of Orthodox Theology were "hostile", with little chance for compromise, but the differences were not seen as ideological because the communists were keeping it secret and did not want to admit it even after numerous hints and accusations that they were present among the students of the Faculty of Orthodox Theology in Belgrade.

On June $7^{\text {th }}, 1939$, the Dean of the Faculty of Orthodox Theology, Professor Radivoj Josić, informed the Council of the Faculty of Orthodox Theology that he received an anonymous letter from the students of the Faculty of Orthodox Theology, the same letter also being to the Minister of Education of the Kingdom of Yugoslavia Stevan Ćirić and the Holy Synod of the Serbian Orthodox Church, "accusing the old and new leadership of the specialized Association of the Students of the Faculty of Orthodox Theology of leftism and communism and arguing that certain professors of the Faculty were helping them"12.

At the Session of the Council of the Faculty of Orthodox Theology on June $30^{\text {th }}$, 1939, Josić said that the Holy Synod of the Serbian Orthodox Church requested the opinion from the Faculty of Orthodox Theology. Then he read the anonymous letter saying that "Mr Minister of Education accused Mr University Rector, Dean of the Faculty of Orthodox Theology and Mr Jordan Ilić PhD Professor of the Faculty of Orthodox Theology for helping the illegal operation of the old and the new management board of the Association of Students of the Faculty of Theology, arguing that it - association - represented the leftists at our university and served leftistcommunist goals". On June 22 $2^{\text {nd }}, 1939$, the Association of Students of the Faculty of Orthodox Theology sent a letter to the Minister of Education "in response to the accusations and slanders of some students"13.

It the end, the Council of the Faculty of Orthodox Theology issued

11 *** “Beleške", in Svetosavlje, October, 1937, Belgrade, p. 143-144.

12 APBF, Minutes from the meeting of the Council of the Faculty of Orthodox Theology, 7 June 1939.

${ }_{13} \mathrm{APBF}$, Minutes from the meeting of the Council of the Faculty of Orthodox Theology, 30 June 1939. 
ARS LITURGICA. From the Image of Glory to the Images of the Idols of Modernity

the requested "decision and opinion": "The Council of the Faculty of Orthodox Theology rejects the very idea that the Dean of the Faculty of Orthodox Theology (Mr. Radivoj Josić, PhD) and Professor at the Faculty of Orthodox Theology (Mr. Jordan Ilić, PhD) are helping or spreading the communist ideas at the Faculty of Orthodox Theology or have anything at all with the communist propaganda; as for the students, the Council of the Faculty of Orthodox Theology could not be sure, from the content of the anonymous letter, that there was - at least for now - the communist propaganda among the students of the Faculty of Orthodox Theology"14.

Ljubodrag Popović, a historian and former head at the Archives of Serbia, whose father, Dr. Atanasije Popović taught at the Faculty of Orthodox Theology, argues that neither their godfather Radivoj Josić nor Jordan Ilić were sympathizers of communists; it was a slander ${ }^{15}$. Rumours could have been spread to undermine the order at the Faculty of Orthodox Theology. However, the Council of the Faculty of Orthodox Theology at that time did not seem to have any knowledge about the operations of the communists within the Association of Students of the Faculty of Orthodox Theology. In 1939, for the purpose of concealing subversive activities, this Association incorrectly informed the Minister of Education that there were no communist activities in their ranks.

The fond of the Ministry of Education of the Kingdom of Yugoslavia does not contain the anonymous letter of the students of the Faculty of Orthodox Theology nor the answer of the Association of Students of the Faculty of Orthodox Theology, or the opinion of the Council of the Faculty of Orthodox Theology ${ }^{16}$.

In 1937, Pero Jovanović came to the position of the editor in chief of Svetosavlje, the journal of the Association of Students of the Faculty of Orthodox Theology. Other members of Editorial board were Ljutovid Milatović, Čedomir Drašković, Jovan Kostić and Đorđe Pejovićc ${ }^{17}$. In 1964, Vurdelja wrote that before World War II Pero Jovanović and Jovan Kostić were open to communist ideas and that, like Živojin Munjić, in the

\section{${ }^{14}$ Ibidem.}

${ }^{15}$ From the Interview with Ljubodrag Popović, 20 October 2008 - Radivoj Josić was a godfather to Ljubodrag Popović.

${ }^{16}$ Archives of Yugoslavia, Ministry of Education of the Kingdom of Yugoslavia, Fund 66, File 155.

17 *** "Beleške", in Svetosavlje, December, 1937, Belgrade, p. 156. 
Federal People's Republic of Yugoslavia, they become members of the Communist Party ${ }^{18}$. Ljubodrag Popović claims that after the World War II, Pero Jovanović became a local communist leader in Pančevo and that another famous student of the Faculty of Orthodox Theology, whose name he could not remember, became an active member of the Communist Party of Yugoslavia ${ }^{19}$. Đoko Slijepčević claims that some "left wing" students took over Svetosavlje and that the founders of this journal of national orientation, including him, gathered around the journal Put and Hrišćanska misao ${ }^{20}$.

After overtaking the Association of Students of the Faculty of Orthodox Theology and journal Svetosavlje, the communists, although few at the Faculty of Orthodox Theology, showed significant organizational strength. Various skirmishes among the students at the Faculty of Orthodox Theology in Belgrade, misunderstandings and disagreements, were fertile ground for the activities of ideological opponents - communists - who, from 1936 to 1941, became engaged in subversive activities towards students' organizations and groups at the Faculty of Orthodox Theology. Students of communist orientation used mimicry and provoked conflicts wherever they could in order to achieve their goal more easily: to take over what can be taken of the student organizations and the media.

\section{References}

1. Archives of Yugoslavia, Ministry of Education of the Kingdom of Yugoslavia, Fond 66, File 155.

2. Archives of the Faculty of Orthodox Theology, Minutes from the meeting of the Council of the Faculty of Orthodox Theology, 7 June 1939.

3. Archives of the Faculty of Orthodox Theology, Minutes from the meeting of the Council of the Faculty of Orthodox Theology, 30 June 1939.

4. Interview with Ljubodrag Popović, former Director of the Archives of Serbia, 20 October 2008.

\footnotetext{
${ }^{18}$ Dragoljub G. Vurdelua, op. cit., p. 63.

${ }^{19}$ From the Interview with Ljubodrag Popović, 20 October 2008.

${ }^{20}$ Đoko SLIJEPČEVIĆ, op. cit., p. 16-17.
} 
5. *** "Assembly of the Association and Choir of Theology Students", in Studentske novine, 10 November 1937.

6. *** "Before the Assembly of the Association and Choir of Theology Students", in Studentske novine, 10 November 1937.

7. *** "Beleške", in Svetosavlje, October, Belgrade 1937.

8. *** "Beleške", in Svetosavlje, December, Beograd 1937.

9. BonDžIĆ, Dragomir, Beogradski univerzitet 1944-1952, Belgrade, Institut za savremenu istoriju, 2004.

10. DAmJAnOviĆ, Milica, Napredni pokret studenata Beogradskog univerziteta, II, Belgrade, Nolit, 1974.

11. SLIJEPČEVIĆ, Đoko istorija srpske pravoslavne crkve, III, Belgrade, BIGZ, 1991.

12. VURDELJA, Dragoljub G., Obezglavljena Srpska crkva, I, Trieste, 1964. 